\title{
変位法および応力法による立体トラスの構造解析 \\ STRUCTURAL ANALYSIS OF SPACE TRUSS BY DISPLACEMENT METHOD AND FORCE METHOD
}

\author{
花井重 孝*1, 川島 晃*2, 石丸 麟太郎*3, 田中 尚*4 \\ Shigetaka HANAI, Akira KAWASHIMA, Rintaro ISHIMARU \\ and Hisashi TANAKA
}

\begin{abstract}
The purpose of this study is to propose a systematic solution for the displacement method and the forced method, based on the kinematical and statical relation equations of a space truss. A simple algorithm is chiefly used for calculating the displacement method. On the other hand, Because it is necessary to remodel a statically indeterminate structure to a statically determinate principal system, the force method is unsuitable for analyzing complex structures. In this paper, the force method will chiefly be described using the general inverse matrix. Moreover, by using the proposed analytical technique it is easy to structure an algorithm.
\end{abstract}

Keywords : small displacement, small strain, generalized inverse matrix, orthogonal projection matrix, self-equilibrated stress, force method

微小変位、微小ひずみ、一般逆行列、直交射影行列、自己釣合応力、态力法

\section{1.はじめに}

本研究は、構造力学の新しい解析法を提案するものではないが、 解析の基礎式において、系全体の幾何学的関係式と力の釣合式およ び構成式に基づく変位法と応力法の系統的な手法を提案することを 主たる目的としている。

変位法は、アルゴリズムが比較的平易でマトリックス理論にも乗 り易く、現在、最も一般的に用いられている。一方、古典的な構造 力学の払張である応力法は、力の釣合条件を満たす応力場を仮定し、 不静定力に関してコンプリメンタリーエネルギー最小の原理を用い るから、不静定構造物を基本力系と不静定力系に分離する必要があ るため複雑な構造物の解法には不向きであるとされている。この古 典的な応力法と階数法を合体したマトリックス構造解析法として、 階数応力法が提案されている1)。

本論文は、微小変位の範囲における安定な立体トラスについて、 古典的な応力法に着目したもので、力の釣合式の一般解の解法にム 一ア・ペンローズ一般逆行列 ${ }^{2)}$ を用いることにより、理論構成は単 純かつわかりやすく、アルゴリズムも簡絜となることを示す。

非線形問題の構造解析における数値計算法として有効な一般逆行 列を用いた研究は、1980年代初頭から盛んに行われている。ここに、 主な研究を概観する。M.Domaszewskiら ${ }^{3)}$ は、コンプリメンタリー
エネルギー最小の原理にBott-Duffin 逆行列を適用した応力法系の 解法を提案している。この提案と本論文の第 4 節の内容との関係は 巻末の [付録] に説明してある。田中・半谷 ${ }^{4)}$ は、ムーア・ペンロ 一ズの一般逆行列による線形方程式の解の存在条件をトラスの分類 に利用するとともに、哃体としての運動の自由度をもつ不安定構造 に関する安定化条件などの理論的考察を行っている。半谷・川口票 は、不安定構造の安定化移行過程の解析や形態解析などの非線形問 題の解析に応用している。その他、和田・久保田 ${ }^{6)}$ は材料非線形問 題を扱う際に生じる不釣合力を合理的に解除する方法に、西村・森 ${ }{ }^{7}{ }^{7)}$ は釣合経路上の臨界点位置を予測するための方法に一般逆行列 を応用している。

なお、本論文では、解析の理論構成を重視する目的から、立体卜 ラスは等断面直線材で構成されるものと仮定し、系全体の基礎式を 定式化している。

\section{2.解析に用いる基礎式}

立体トラス全体の基礎式を述べる。幾何学的関係式と力の釣合式 は、空間固定の直交デカルト座標系（空間固定座標系）で記述する。 本論文で用いる記号は英文字とギリシャ文字で、小文字細字はス カラー、小文字太字はベクトル、大文字太字はマトリックスを表す。
*1 日本大学生産工学部建築工学科 助教授 ·工博

*2 日本大学生産工学部建築工学科 専任講師 - 工修

*3 日本大学大学院生産工学研究科建築工学専攻 講師 · 工博

*4 東京大学 名誉教授.工博
Assoc. Prof., Dept. of Architecture and Architectural Eng., College of Industrial Technology, Nihon Univ., Dr. Eng.

Lecturer, Dept. of Architecture and Architectural Eng., College of Industrial Technology, Nihon Univ., M. Eng.

Lecturer, Dept. of Architecture and Architectural Eng., Graduate School of Industrial Technology, Nihon Univ., Dr. Eng.

Prof. Emeritus, University of Tokyo, Dr. Eng. 


\section{1 线何学的関係式}

図2.1において、 $x_{1}-x_{2}-x_{3}$ は空間固定座標系を示す。(p) は 部材名であり、(A) と (B) は部材 ( $\mathrm{P}$ )の材端が接続する節点名である。

$\boldsymbol{x}_{(\mathrm{A})}$ と $\boldsymbol{x}_{(\mathrm{B})}$ および $\mathbf{u}_{(\mathrm{A})}$ と $\mathbf{u}_{(\mathrm{B})}$ は、節点 $(\mathrm{A})$ と(B) の位置ベクトル および節点変位べクトルである。 $\lambda(\mathrm{p})$ は、部材 $(\mathrm{p})$ の方向を示す単 位ベクトルて、、節点番号の小さい方から大きい方へ向かって取るこ とにし、節点番号の小さい方を節点 $(\mathrm{A})$ ，大きい方を節点 $(\mathrm{B})$ とする。

部材 $(\mathrm{p})$ の材長を $\ell(\mathrm{p})$ とすると、

$$
\ell(\mathrm{p}) \boldsymbol{\lambda}(\mathrm{p})=\left[-\boldsymbol{x}_{(\mathrm{A})}+\boldsymbol{x}_{(\mathrm{B})}\right]
$$

で、

$$
\ell(\mathrm{p})=\left\{\left[\boldsymbol{x}_{(\mathrm{B})}-\boldsymbol{x}_{(\mathrm{A})}\right]^{\mathrm{T}}\left[\boldsymbol{x}_{(\mathrm{B})}-\boldsymbol{x}_{(\mathrm{A})}\right]\right\}^{\frac{1}{2}}
$$

である。ここに、局付き添字 $\mathrm{T}$ は転置を表す。

部材 $(\mathrm{p})$ の伸びを $\Delta \ell(\mathrm{p})$ とすると、

$$
\left[\begin{array}{ll}
-\lambda_{(\mathrm{p})}^{\mathrm{T}} & \lambda^{\mathrm{T}}(\mathrm{p})
\end{array}\right]\left[\begin{array}{l}
\mathbf{u}_{(\mathrm{A})} \\
\mathbf{u}_{(\mathrm{B})}
\end{array}\right]=\Delta \ell(\mathrm{p})
$$

である。

立体トラズ全体に対して式(2.3)を適用するために、図2.2のよう な立体トラスの一部分を取り出して説明する。

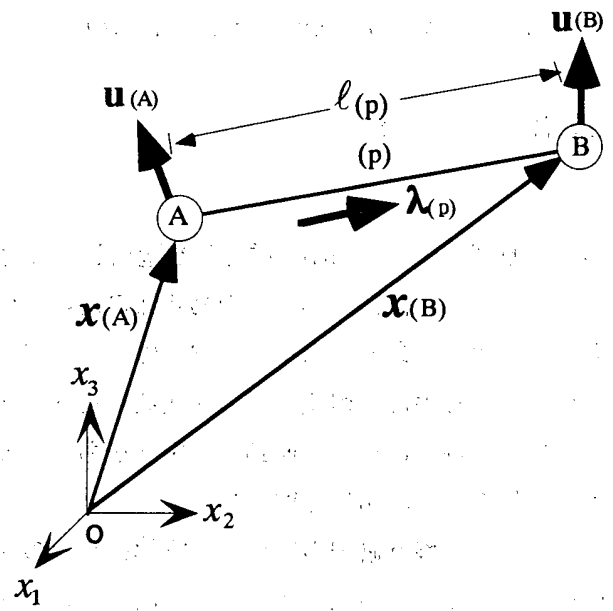

図2.1 座標系

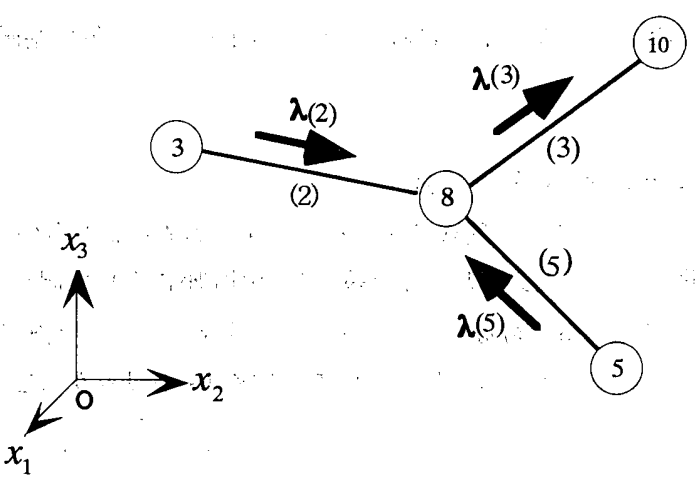

図2.2 部材と節点の関係
部材 (p) と節点 (A) (B) の関係は、表2.1のようになる。表 2.2 は、 表2.1の関係をマトリックスの形で示してある。式(2.3)に示す節点 変位ベクトル $\mathbf{u}_{(\mathrm{A})}, \mathbf{u}_{(\mathrm{B})}$ と伸び $\Delta \ell(\mathrm{p})$ の関係式を見ると、 $\mathbf{u}_{(\mathrm{A})}$ に $-\lambda^{\mathrm{T}}{ }_{(\mathrm{p})}$ が付き、 $\mathbf{u}_{(\mathrm{B})}$ に $\boldsymbol{\lambda}_{(\mathrm{p})}^{\mathrm{T}}$ が掛けられているから表 2.2 を参照し て、節点変位ベクトルと伸びの関係式を作ると表 $2.3 か ゙$ 得られる。

表2.3を全部材、全節点に拡張し固定されている境界の節点变位 成分を零として消去し出来上がったマトリックスを $\mathbf{A}$ とおけば、

$$
\mathbf{A u}=\Delta
$$

が得られる。ここに、u は系全体の節点変位ベクトルであり自由 度数を $\mathrm{n}$ とし、 $\Delta \boldsymbol{l}$ は伸びベクトルであり部材数を $\mathrm{m}$ とすると、

$\mathrm{A}$ は $(\mathrm{m} \times \mathrm{n})$ のマトリックスとなる。

表2.1 部材と節点の関係

\begin{tabular}{|l|c|c|c|}
\hline 部材 $(\mathrm{p})$ & 2 & 3 & 5 \\
\hline 節点 $(\mathrm{A})$ & 3 & 8 & 5 \\
\hline 節点 $(\mathrm{B})$ & 8 & 10 & 8 \\
\hline
\end{tabular}

\begin{tabular}{|c|c|c|c|c|}
\hline 節点 & $\mathbf{u}(3)$ & $\mathbf{u}_{(5)}$ & $\mathbf{u}(8)$ & $\mathbf{u}_{(10)}$ \\
\hline & $i$ & & & \\
\hline$\Delta \ell(2)$ & $-\lambda^{\mathrm{T}}{ }_{(2)}$ & & $\lambda^{\mathrm{T}}(2)$ & \\
\hline$\Delta \ell(3)$ & & & $-\lambda^{\mathrm{T}}$ & $\lambda^{\mathrm{T}}(3)$ \\
\hline & & & & $\therefore$ \\
\hline$\Delta \ell(5)$ & . & $-\lambda^{\top}(5)$ & $\boldsymbol{\lambda}^{\mathrm{T}}(5)$ & \\
\hline & & & & \\
\hline
\end{tabular}

表2.2 部材と節点の関係（行列表示）

\begin{tabular}{|c||c|c|c|c|c|c|c|c|c|}
\hline & 3 & & 5 & & 8 & & 10 & \\
\hline 2 & & A & & & & B & & & \\
\hline 3 & & & & & & A & & B & \\
\hline & & & & & & & & & \\
\hline
\end{tabular}

表2.3 適合マトリックス $\mathbf{A}$

\section{2 力の釣合式}

部材 $(p)$ の軸応力 $n(p)$ （引張力を正）で作る軸応力ベクトルを $\mathbf{n}$ とし、節点変位の自由度に対応した荷重ベクトルを $\mathbf{f}$ で表す。 仮想の節点変位ベクトルを $\underline{\mathbf{u}}$ とし、 $\underline{\mathbf{u}}$ によって起こる伸びベク トルを $\Delta l$ とすると、仮想仕事の原理より式(2.5)が成立する。 


$$
\mathbf{n}^{\mathrm{T}} \underline{\Delta l}=\mathbf{f}^{\mathrm{T}} \underline{\mathbf{u}}
$$

式(2.5)に式(2.4)を適用すると、

$$
\begin{gathered}
\mathbf{n}^{\mathrm{T}} \mathbf{A} \underline{\mathbf{u}}=\mathbf{f}^{\mathrm{T}} \underline{\mathbf{u}} \\
{\left[\mathbf{n}^{\mathrm{T}} \mathbf{A}-\mathbf{f}^{\mathrm{T}}\right] \mathbf{u}=\mathbf{0}}
\end{gathered}
$$

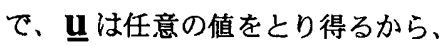

$$
\mathbf{n}^{\mathrm{T}} \mathbf{A}=\mathbf{f}^{\mathrm{T}} \quad, \quad \mathbf{A}^{\mathrm{T}} \mathbf{n}=\mathbf{f} \quad(2.7 \mathrm{a}, \mathrm{b})
$$

が成立する。

式(2.4)と式(2.7) の関係は、反傾原理と呼ばれている。 式(2.7)において、

$$
\mathbf{A}^{\mathrm{T}}=\mathbf{B}
$$

とおくと、立体トラス全体の釣合式は、

$$
\mathbf{B n}=\mathbf{f}
$$

で、Bは表2.3を参照すると表 2.4 の形をしていることが分かる。こ こに、Bは反候原理より $(\mathrm{n} \times \mathrm{m})$ のマトリックスである。

表2.4 釣合マトリックス $\mathbf{B}$

\begin{tabular}{|c|l|l|l|l|l|l||}
\hline 節点 & & $\mathrm{n}_{(2)}$ & $\mathrm{n}_{(3)}$ & & $\mathrm{n}(5)$ & \\
\hline & & & & & & \\
\hline $\mathbf{f}(3)$ & & $-\lambda(2)$ & & & & \\
\hline & & & & & & \\
\hline $\mathbf{f}(5)$ & & & & & $-\lambda(5)$ & \\
\hline & & & & & & \\
\hline $\mathbf{f}(8)$ & & $\lambda(2)$ & $-\lambda(3)$ & & $\lambda(5)$ & \\
\hline & & & & & & \\
\hline $\mathbf{f}(10)$ & & & $\lambda(3)$ & & & \\
\hline & & & & & & \\
\hline
\end{tabular}

\section{3 構成式}

構成式はヤング係数を $\mathrm{E}$ とし、部材 (p) の断面積を $\mathrm{A}$ (p) とし次式 を用いる。

$$
\mathrm{n}(\mathrm{p})=\frac{\mathrm{EA}(\mathrm{p})}{\ell(\mathrm{p})} \Delta \ell(\mathrm{p})
$$

上式で、

$$
\mathrm{k}(\mathrm{p})=\frac{\mathrm{EA}(\mathrm{p})}{\ell(\mathrm{p})} \quad, \quad \mathrm{s}(\mathrm{p})=\frac{\ell(\mathrm{p})}{\mathrm{EA}(\mathrm{p})}
$$

とおき、軸応カベクトル $\mathbf{n}$ と伸びベクトル $\Delta \boldsymbol{l}$ の関係式は、

$$
\mathrm{n}=\mathrm{K} \Delta l \quad, \quad \Delta l=\mathbf{S n}
$$

$(2.12 \mathrm{a}, \mathrm{b})$

で表す。ここに、右辺の $\mathbf{K}$ と $\mathbf{S}$

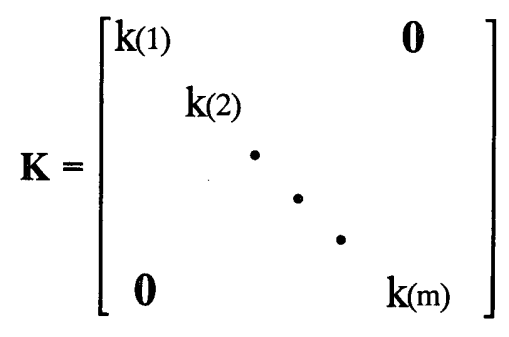

である。

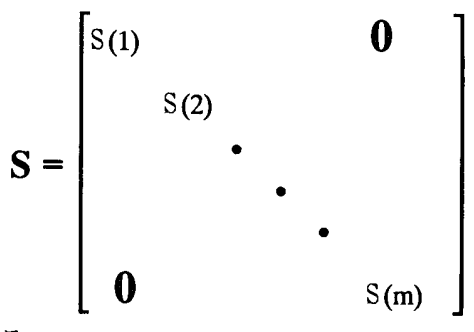

\section{3. 变位法}

系全体の構成式 $(2.12 \mathrm{a})$ の両辺に $\mathrm{A}^{\mathrm{T}}$ を左から掛ける。

$$
\mathbf{A}^{\mathrm{T}} \mathbf{n}=\mathbf{A}^{\mathrm{T}} \mathbf{K} \Delta \boldsymbol{l}
$$

上式右辺の $\Delta l$ に式(2.4)を代入する。

$$
\begin{aligned}
\mathbf{A}^{\mathrm{T}} \mathbf{n} & =\mathbf{A}^{\mathrm{T}} \mathbf{K A u} \\
& =\mathbf{H u} \\
こ こ に 、 & \\
\mathbf{H}= & \mathbf{A}^{\mathrm{T}} \mathbf{K A}
\end{aligned}
$$

とおき、式(2.7b) を使うと、

$$
\mathbf{H u}=\mathbf{f}
$$

となる。

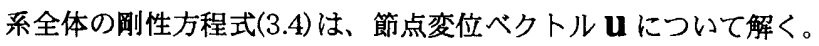
本論文では、1．はじめにで述べた様に安定トラスを扱う。した がって、系全体の剛性マトリックス $\mathbf{H}$ は正則マトリックスであるか ら、その逆行列 $\mathbf{H}^{-1}$ を用いて、

$$
\mathbf{u}=\mathbf{H}^{-1} \mathbf{f}
$$

で、節点変位ベクトル $\mathbf{u}$ を一意に求めることが出来る。

軸応力ベクトルnは、式(2.12 a)と式(2.4) から次式で求める。

$$
\mathbf{n}=\mathbf{K A u}
$$

\section{4. 応力法}

系全体の力の釣合式(2.9)の一般解は、ムーアペンローズの一般逆 行列（以後、単に一般逆行列と呼称し、マトリックスの右上局に+ を付けて表示する）を用いて次式で表せる。

$$
\mathbf{n}=\mathbf{B}^{+} \mathbf{f}+\left[\mathrm{Im}_{\mathrm{m}}-\mathbf{B}^{+} \mathbf{B}\right] \boldsymbol{B}
$$

ここに、 $\boldsymbol{\beta}$ は $\mathrm{m}$ 次元の任意ベクトルであり、 $\mathbf{I} \mathrm{m}$ は $(\mathrm{m} \times \mathrm{m})$ の単 位マトリックスである。

式(4.1)右辺第 2 項の係数マトリックスは反傾原理より、

$$
\left[\mathbf{I}_{\mathrm{m}}-\mathbf{B}^{+} \mathbf{B}\right]=\left[\mathbf{I}_{\mathrm{m}}-\mathbf{A A}^{+}\right]
$$

となる。上式は $\mathrm{m}$ 個の列ベクトルをもつが、そのうちの独立な列べ 
クトルを $\mathbf{g}_{1}, \mathbf{g}_{2}, \cdots, \mathbf{g}_{\mathrm{q}}$ とすと、

$$
\begin{aligned}
{\left[\operatorname{Im}_{\mathrm{m}}-\mathbf{B}^{+} \mathbf{B}\right] } & =\left[\mathbf{I m}_{\mathrm{m}}-\mathbf{A A}^{+}\right] \\
& =\left[\mathbf{g}_{1}, \mathbf{g}_{2}, \cdots, \mathbf{g}_{\mathrm{q}}: \mathbf{g}_{\mathrm{q}+1}, \mathbf{g}_{\mathrm{q}+2}, \cdots, \mathbf{g}_{\mathrm{m}}\right]
\end{aligned}
$$

である。

式(4.1)の右辺第 2 項 $\left[\mathbf{I m}-\mathbf{B}^{+} \mathbf{B}\right] \boldsymbol{\beta}$ は、 $\boldsymbol{\beta}$ が任意ベクトルである ことを考慮すると式(4.3)の独立な列ベクトル $\mathrm{g}_{1}, \mathrm{~g}_{2}, \cdots, \mathbf{g}_{\mathrm{q}}$ を用い $\tau$.

$$
\left[\mathrm{Im}-\mathbf{B}^{+} \mathbf{B}\right] \boldsymbol{\beta}=\left[\beta_{1} \mathbf{g}_{1}+\beta_{2} \mathbf{g}_{2}+\cdots+\beta_{\mathrm{q}} \mathbf{g}_{\mathrm{q}}\right]
$$

で表すことが出来る。ここに、下付き添字 $\mathrm{q}$ は、力の釣合式(2.9)の みでは求められない応力数を表すから、通常、不静定次数と呼ばれ ている。

式(4.1)は式(4.4)を使って、

$$
\mathbf{n}=\mathbf{B}^{+} \mathbf{f}+\left[\beta_{1} \mathbf{g}_{1}+\beta_{2} \mathbf{g}_{2}+\cdots+\beta_{\mathrm{q}} \mathbf{g}_{\mathrm{q}}\right]
$$

さらに、

$$
\mathbf{n}=\mathbf{n}^{\mathrm{P}}+\mathbf{n}^{\mathrm{c}}
$$

とおき

$$
\begin{aligned}
& \mathbf{n}^{\mathrm{P}}=\mathbf{B}^{+} \mathbf{f} \\
& \mathbf{n}^{\mathrm{c}}=\left[\beta_{1} \mathbf{g}_{1}+\beta_{2} \mathbf{g}_{2}+\cdots+\beta_{\mathrm{q}} \mathbf{g}_{\mathrm{q}}\right]
\end{aligned}
$$

とすると、 $\mathbf{n}^{\mathrm{P}}$ は特解で、 $\mathbf{n}^{\mathrm{c}}$ は余解である。

式(4.8)に示す余解 $\mathbf{n}^{\mathrm{C}}$ は、荷重 $\mathbf{f}$ に関係なく生じるから自己釣合 の応力を表す。

構成式(2.12b)の $\mathbf{n}$ に式(4.8)の $\mathbf{n}^{\mathrm{c}}$ を代入し、伸びベクトル $\Delta l$ を $\Delta l^{\mathrm{c}}$ に、 $\beta_{\mathrm{i}}(\mathrm{i}=1,2, \cdots, \mathrm{q})$ を $\gamma_{\mathrm{i}}$ に書き変えると、

$$
\Delta l^{\mathrm{c}}=S\left[\gamma_{1} \mathbf{g}_{1}+\gamma_{2} \mathbf{g}_{2}+\cdots+\gamma_{\mathrm{q}} \mathbf{g}_{\mathrm{q}}\right]
$$

となる。上式右辺の $\gamma_{\mathrm{i}}$ に対応する列ベクトルを、

$$
S \boldsymbol{g}_{\mathrm{i}}=\mathbf{h i}_{\mathrm{i}}
$$

とおくと、

$$
\Delta l^{\mathrm{c}}=\gamma_{1} \mathbf{h} 1+\gamma_{2} \mathbf{h} 2+\cdots+\gamma_{\mathrm{q}} \mathbf{h q}
$$

となる。ここに、 $\gamma_{\mathrm{i}(\mathrm{i}=1,2, \cdots, \mathrm{q})}$ は任意の值を取り得るから、

$$
\gamma_{\mathrm{i}}=1 \quad, \gamma_{\mathrm{j}}=0 \quad(\mathrm{j} \neq \mathrm{i})
$$

とおき、式(4.11)の $\Delta l^{\mathrm{c}}$ と式(4.5)の $\mathrm{n}$ に仮想仕事の原理を適用する と、次式が得られる。

$$
\begin{aligned}
& \quad \mathbf{h i}^{\mathrm{T}} \mathbf{B}^{+} \mathbf{f} \\
& \quad+\mathbf{h i}^{\mathrm{T}} \mathbf{g}_{1} \gamma_{1}+\mathbf{h i}^{\mathrm{T}} \mathbf{g}_{2} \gamma_{2}+\cdots+\mathbf{h}^{\mathrm{T}} \mathbf{g}_{\mathrm{q}} \gamma_{\mathrm{q}}=0 \\
& \text { ここに, } \\
& \mathbf{h i}^{\mathrm{T}} \mathbf{B}^{+} \mathbf{f}=\delta_{\mathrm{i} 0}, \quad \mathbf{h i}^{\mathrm{T}} \mathbf{g}_{\mathrm{j}}=\delta_{\mathrm{ij}}
\end{aligned}
$$

とおくと、式(4.13)は、

$$
\delta_{i 0}+\sum_{j=1}^{q} \delta_{i j} \gamma_{j}=0
$$

となる。上式を書き下すと、

$$
\left\{\begin{array}{l}
\delta 10+\delta 11 \gamma_{1}+\delta 12 \gamma_{2}+\cdot \cdot+\delta 1 \mathrm{q} \gamma_{\mathrm{q}}=0 \\
\delta 20+\delta 21 \gamma_{1}+\delta 22 \gamma_{2}+\cdot \cdot+\delta 2 \mathrm{q} \gamma_{\mathrm{q}}=0 \\
\cdot \cdot \cdot \cdot \\
\delta \mathrm{q} 0+\delta \mathrm{q} 1 \gamma_{1}+\delta \mathrm{q} 2 \gamma_{2}+\cdot \cdot+\delta \mathrm{qq} \gamma_{\mathrm{q}}=0
\end{array}\right.
$$

である。

式(4.16)を $\gamma_{\mathrm{i}}$ について解く。 $\gamma_{\mathrm{i}}=\beta_{\mathrm{i}}$ として式(4.5)に代入する と軸応力ベクトル $\mathbf{n}$ が求まる。 $\mathbf{n}$ を式(2.12b)に代入すると伸びべ クトル $\Delta \boldsymbol{l}$ が求まる。続いて、節点変位ベクトル $\mathbf{u}$ は、安定トラス では式(2.4)より、

$$
\mathbf{u}=\mathrm{A}^{+} \Delta l=\left(\mathrm{B}^{+}\right)^{\mathrm{T}} \Delta l
$$

で求まる。

\section{5. 応力法の例題}

\section{1 例題 1 : アルゴリスム}

図5.1は本応力法のアルゴリズムで、図5.2に示す簡単な立体トラ スの例題を用いて解説する。また、階数応カ法 ${ }^{1)}$ のアルゴリズム と比較検討した結果を述べる。

図5.2において、数字は節点番号を、（）付きの数字は部材番 号を表している。荷重は、同図(b)に示すように水平 $x_{2}$ 方向と鈶直 $x_{3}$ 方向に載荷している。軸周性 $\mathrm{EA}(\mathrm{p})$ は、部材 (2)(3)(5)(6)は同一

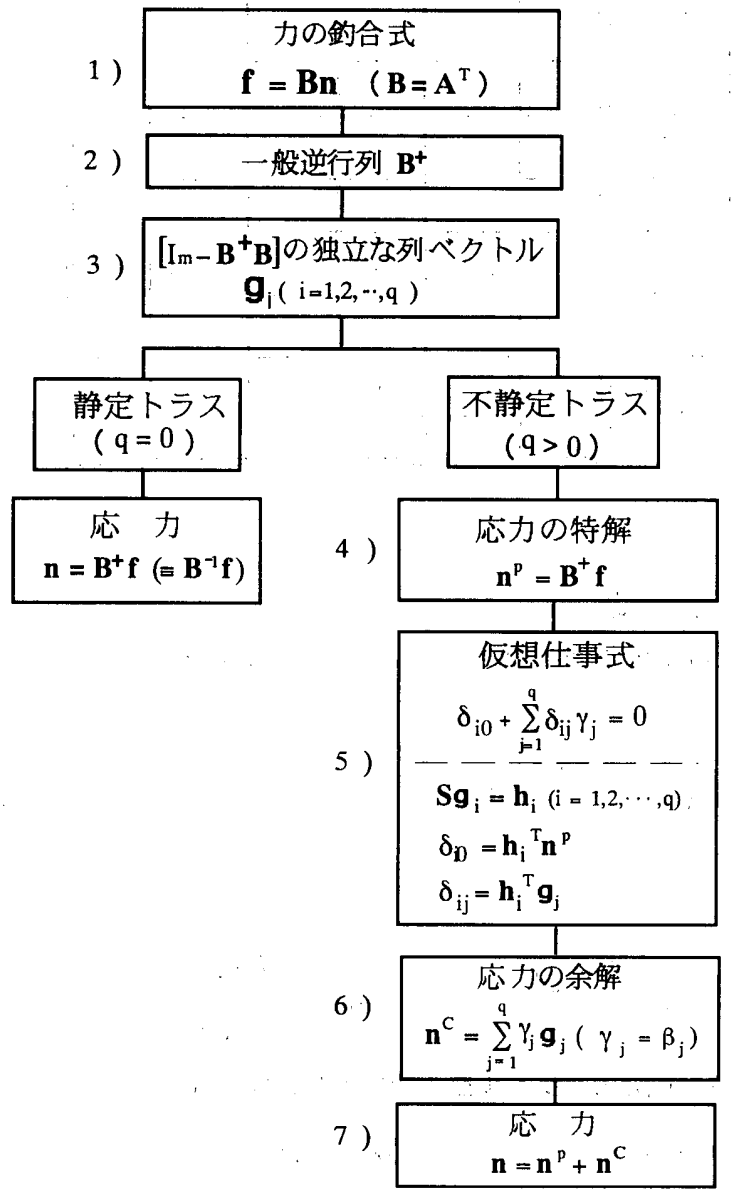

図5.1 本応力法のアルゴリズム 
$(\mathrm{EA}(2)=\mathrm{EA}(3)=\mathrm{EA}(5)=\mathrm{EA}(6)=\mathrm{EA})$ で、部材(1)(4)はその 1.2 倍 $\left(\mathrm{EA}(1)=\mathrm{EA}_{(4)}=1.2 \mathrm{EA}\right)$ としている。

\section{（1）本応力法のアルコリスム（图5.1）}

解法手䐓 1) カの知合式の作成

カの釣合式(2.9)において、

軸応力ベクトル $\mathbf{n}=\{\mathrm{n}(1), \mathrm{n}(2), \mathrm{n}(3), \mathrm{n}(4), \mathrm{n}(5), \mathrm{n}(6)\}^{\mathrm{T}}$ 荷重ベクトル $\mathbf{f}=\mathbf{f}(1)=\{0,1,-1\}^{\mathrm{T}}$

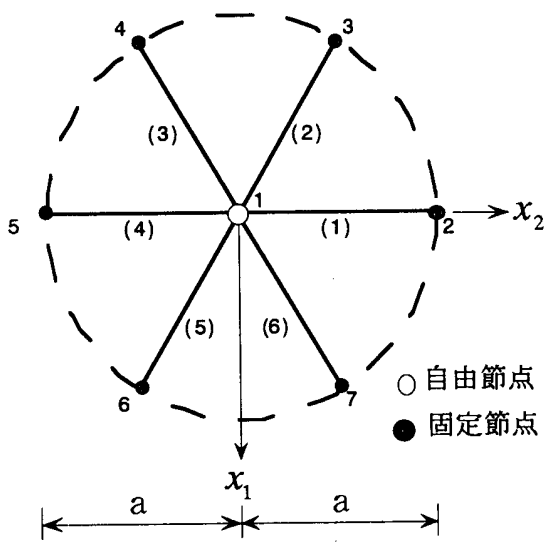

(a) 平面図

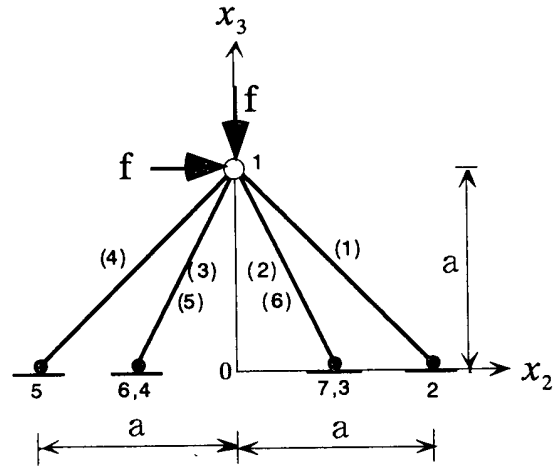

$\mathrm{a}=100 \mathrm{~cm} \quad \mathrm{EA}=6594 \mathrm{KN} \quad \mathrm{f}=1 \mathrm{KN}$ (b) 立面図

図5.2 例題 1

表5.1 部材と節点の関係（例題 1)

\begin{tabular}{|l|l|l|l|l|l|l|}
\hline 部材 $(\mathrm{p})$ & 1 & 2 & 3 & 4 & 5 & 6 \\
\hline 節点(A) & 1 & 1 & 1 & 1 & 1 & 1 \\
\hline 節点 $(\mathrm{B})$ & 2 & 3 & 4 & 5 & 6 & 7 \\
\hline
\end{tabular}

表5.2 各部材の方向余弦ベクトル $\boldsymbol{\lambda}^{\mathrm{T}}(\mathrm{p})$ (例題 1)

\begin{tabular}{|c|c|c|c|c|}
\hline \multirow{4}{*}{ 部材 $(\mathrm{p})$} & 1 & 0 & 0.707 & -0.707 \\
\cline { 2 - 5 } & 2 & -0.612 & 0.354 & -0.707 \\
\cline { 2 - 5 } & 3 & -0.612 & -0.354 & -0.707 \\
\cline { 2 - 5 } & 4 & 0 & -0.707 & -0.707 \\
\cline { 2 - 5 } & 5 & 0.612 & -0.354 & -0.707 \\
\hline & 6 & 0.612 & 0.354 & -0.707 \\
\hline
\end{tabular}

である。

表2.1に示した部材 $(\mathrm{p})$ と節点(A)(B) の関倸は、本例題では表5.1 となる。表 5.2 は、部材 $(\mathrm{p})$ の方向を示す単位ベクトル（方向余弦べ クトル） $\lambda^{\mathrm{T}}{ }_{\mathrm{p})}$ で、表2.4に示した釣合マトリックス $\mathbf{B}$ は、本例題で は次の棣になる。

$$
\mathbf{B}=\left[\begin{array}{cccccc}
0 & 0.612 & 0.612 & 0 & -0.612 & -0.612 \\
-0.707 & -0.354 & 0.354 & 0.707 & 0.354 & -0.354 \\
0.707 & 0.707 & 0.707 & 0.707 & 0.707 & 0.707
\end{array}\right]
$$

解法手頋 2) 一般逆行列 $\mathrm{B}^{+}$の計算

一般逆行列の計算法は特異値分解による方法が一般的で、その他、 ベンーイスラエルの収束計算法など ${ }^{5)}$ がある。本例題の一般逆行列 $\mathbf{B}^{+}$は次の様になる。

$$
\mathbf{B}^{+}=\left[\begin{array}{ccc}
0 & -0.471 & 0.236 \\
0.408 & -0.236 & 0.236 \\
0.408 & 0.236 & 0.236 \\
0 & 0.471 & 0.236 \\
-0.408 & 0.236 & 0.236 \\
-0.408 & -0.236 & 0.236
\end{array}\right]
$$

解法手順 3) $\left[\mathrm{Im}^{-} \mathbf{B}^{+} \mathbf{B}\right]$ の独立列ベクトル $\mathrm{g}_{\mathrm{i}}(\mathrm{i}=1,2, \cdots, \mathrm{q})$ 式(4.1) 右辺第 2 項の係数 マトリックス（直交射影行列） $\left[\operatorname{Im}-\mathbf{B}^{+} \mathbf{B}\right]$ は、次の様になる。

$$
\left[\mathrm{Im}-\mathbf{B}^{+} \mathbf{B}\right]=\left[\begin{array}{ccccccc}
0.5 & & & & & \\
-0.333 & 0.5 & \multicolumn{5}{c}{\text { symmetric }} \\
0 & -0.333 & 0.5 & & & \\
0.167 & 0 & -0.333 & 0.5 & & \\
0 & 0.167 & 0 & -0.333 & 0.5 & \\
-0.333 & 0 & 0.167 & 0 & -0.333 & 0.5
\end{array}\right]
$$

本例題は 3 次不静定 $(q=3$ : 応力数 $m=6$-力の釣合式の数 $\mathrm{n}=3$ ) で、 $\left[\mathrm{Im}-\mathbf{B}^{+} \mathbf{B}\right]$ の独立な列ベクトルは、第 1 列と第 3 列 および第 5 列（直交べクトル）である。

$$
\mathbf{g}_{1}=\left[\begin{array}{c}
0.500 \\
-0.333 \\
0 \\
0.167 \\
0 \\
-0.333
\end{array}\right], \quad \mathbf{g}_{2}=\left[\begin{array}{c}
0 \\
-0.333 \\
0.500 \\
-0.333 \\
0 \\
0.167
\end{array}\right], \quad \mathbf{g}_{3}=\left[\begin{array}{c}
0 \\
0.167 \\
0 \\
-0.333 \\
0.500 \\
-0.333
\end{array}\right]
$$

\section{解法手暊 4 ）応力の特解 $\mathbf{n}^{\mathrm{p}}$ の計算}

応力の特解 $\mathbf{n}^{\mathrm{P}}$ は式(4.7)から次の様になる。

$$
\mathbf{n}^{\mathrm{p}}=\{-0.707,-0.471,0,0.236,0,-0.471\}^{\mathrm{T}} \quad(\mathrm{KN})
$$


解法手頋 5 ）仮想仕事式の作成

まず、粠成式(2.12.b)右辺のSは、

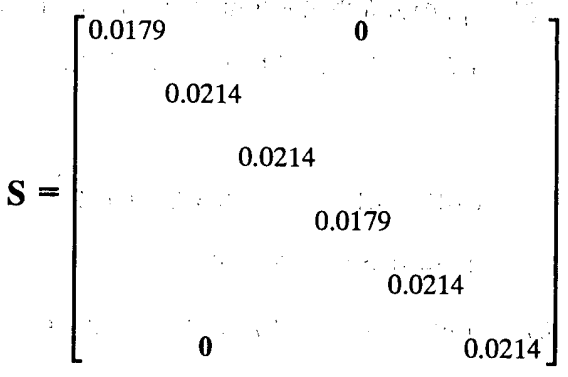

である。仮想仕事式(4.15)は式(4.10)(4.14)より、

$$
\begin{aligned}
& {\left[\begin{array}{l}
1.123 \times 10^{-3} \\
0.281 \times 10^{-3} \\
0.281 \times 10^{-3}
\end{array}\right]} \\
& +\left[\begin{array}{lrr}
9.731 \times 10^{-3} & \text { sym } & \\
0.199 \times 10^{-3} & 10.326 \times 10^{-3} & \\
0.199 \times 10^{-3}-0.397 \times 10^{-3} & 10.326 \times 10^{-3}
\end{array}\right]\left[\begin{array}{l}
\gamma_{1} \\
\gamma_{2} \\
\gamma_{3}
\end{array}\right]=\left[\begin{array}{l}
0 \\
0 \\
0
\end{array}\right]
\end{aligned}
$$

で、 $\gamma_{\mathrm{i}}(\mathrm{i}=1,2,3)$ について解く。

\section{解法手順 6) 応力の余解 $\mathbf{n}^{\mathbf{c}}$ の計算}

応力の余解 $\mathbf{n}^{\mathbf{c}}$ は、 $\gamma_{\mathrm{i}}=\beta_{\mathrm{i}}$ とじて式(4.8)に代入すると、

$\mathbf{n}^{\mathrm{c}}=\{-0.057,0.042,-0.013,-0.002,-0.013,0.042\}^{\mathrm{T}}(\mathrm{KN})$ を得る。

\section{解法手願 7）軸応力 nの計算}

以上、軸応力 $\mathbf{n}$ は式(4.6)より、

$$
\begin{aligned}
\mathbf{n} & =\mathbf{n}^{\mathrm{P}}+\mathbf{n}^{\mathrm{c}} \\
& =\{-0.764,-0.429,-0.013,0.234,-0.013,-0.429\}^{\mathrm{T}}(\mathrm{KN})
\end{aligned}
$$
となる。

（2）階数応力法 ${ }^{1)}$ のアルコリズムの概要

図5.3に階数応力法のアルゴリズムの概要を示す。階数応力法で

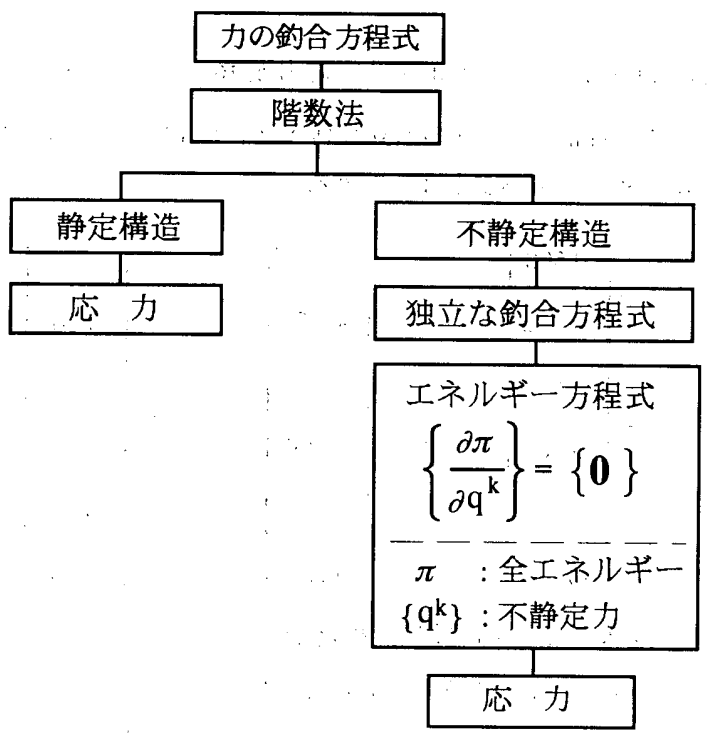

図5.3 階数応力法 ${ }^{1)}$ のアルゴリズムの概要
は、釣合方程式にJordanの消去法を適用し独立な釣合方程式を求め

る。次に不静定構造では、独立な釣合方程式と不静定次数に等しい エネルギー方程式（全エネルギーを分離された不静定力に関して最 小化する）を結合し、これを解くことにより応力が算定される。し たがって、階数応力法は不静定力に関する钓合式を求めるのに、工 ネルギーの停留原理を用いているために、偏導関数マトリックスの 作成などのアルゴリズムが繁雑である。

\section{2 例題 2}

例題 2 は、図5.4に示す鈶直荷重を受ける立体トラスである。 部材名と節点名は、図5.4中に示す通りである。本例題の部材数は $\mathrm{m}=18$ で、変位の自由度数は $\mathrm{n}=9$ であるから、不静定次数は $\mathrm{q}=9$ である。なお、軸剛性EA (p) は全部材同一としている。

図5.5は応力の特解 $\mathbf{n}^{\mathrm{p}}$ であり、図5.6は応力の余解 $\mathbf{n}^{\mathrm{c}}$ における自 己釣合応力モード $\mathbf{g}_{1} \sim \mathbf{g}_{9}$ の一例を示す。図5.7は軸応力図で、( ) 内は第 3 節で述べた変位法による結果である。

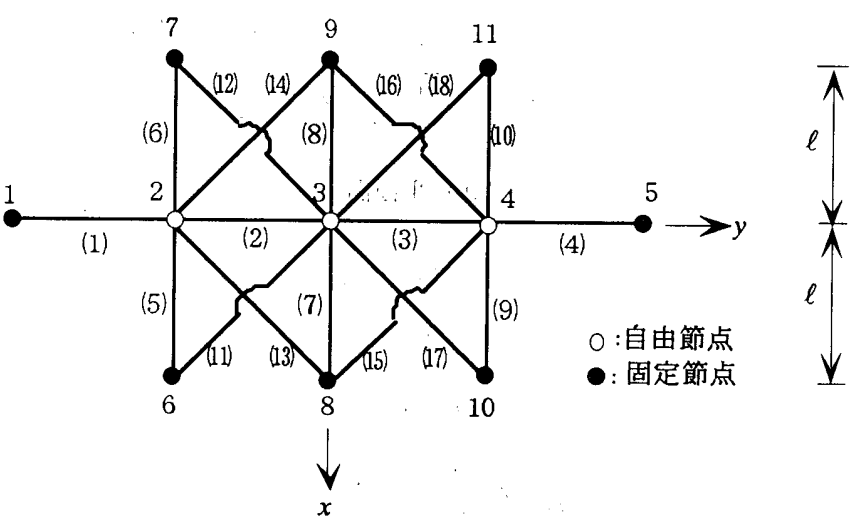

(a) 平面図

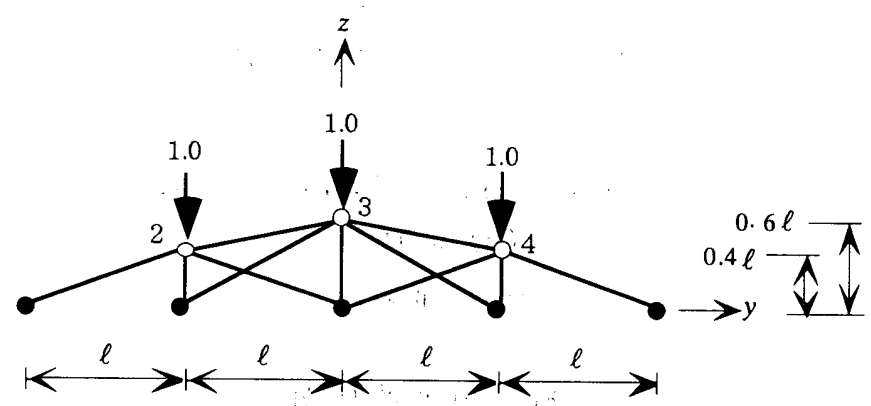

(b) 立面図

図5.4 例題 2

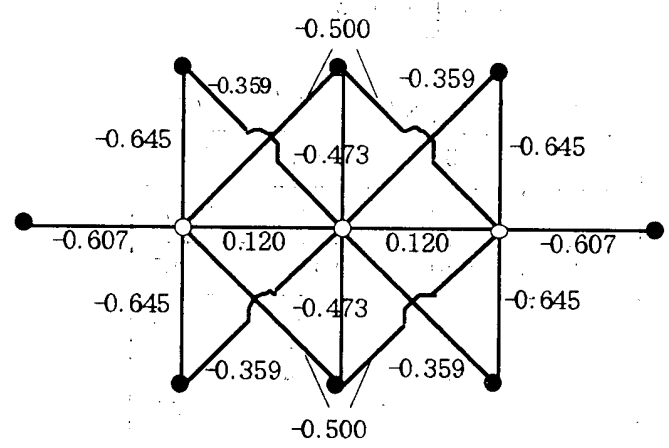

図5.5 応力の特解 $\mathbf{n}^{\mathrm{p}}$ 


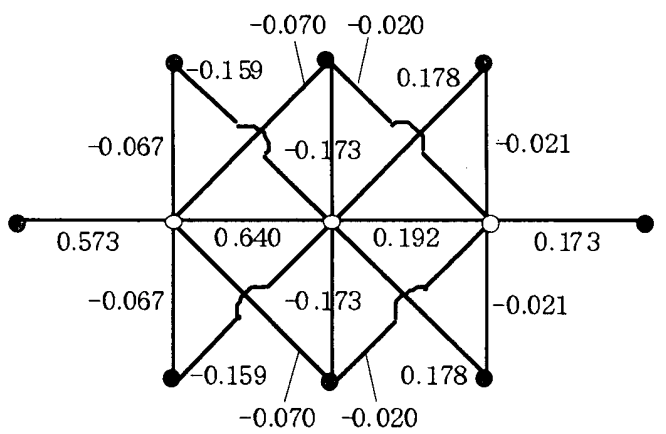

図5.6 自己釣合応力モードの一例

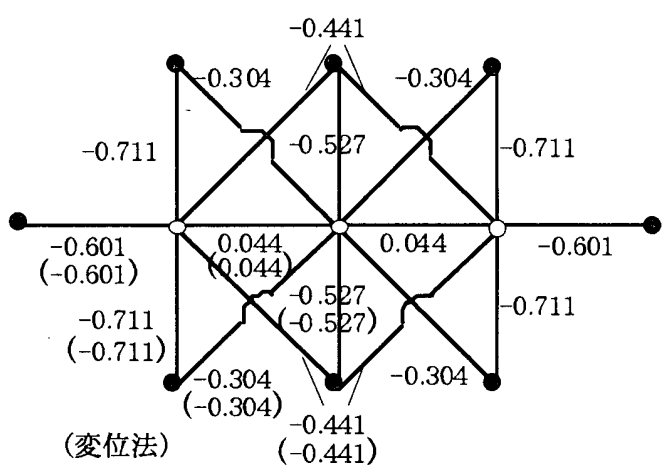

図5.7 軸応力図

\section{6. あとがき}

以上、本論文では、微小变位の範囲における安定な立体トラスに ついて、力の釣合式の一般解の解法に一般逆行列を用いる応力法を 提案した。本応力法は理論構成が単純かつ分かりやすく、アルゴリ ズムも簡絜となることを具体例により示した。なお、本論文では、 解析の理論構成を重視する目的から、等断面直線材で構成された立 体トラスについて、系全体の基礎式を定式化した。

\section{[付錄]}

文献 3 ）は、応力法系の解法を次の関数の制約条件付き最小 値間題として、定式化している。すなわち、

$$
\Pi=\frac{1}{2} \mathbf{n}^{\mathrm{T}} \mathbf{S n}
$$

制約条件

$$
\mathbf{B n}=\mathbf{f}
$$
式(A.1)の Пを $\mathbf{n}$ の各成分で偏微分すると、

$$
\text { Sn }=0
$$

となる。式(A.2)の解は本文式(4.1)(4.6)より、

$$
\mathbf{n}=\mathbf{n}^{\mathrm{P}}+\mathbf{n}^{\mathrm{c}}
$$

$$
\text { ここに、 }
$$

$$
\begin{aligned}
& \mathbf{n}^{\mathrm{P}}=\mathbf{B}^{+} \mathbf{f} \\
& \mathbf{n}^{\mathrm{C}}=\left[\mathbf{I} \mathrm{m}-\mathbf{B}^{+} \mathbf{B}\right] \boldsymbol{\beta}
\end{aligned}
$$

であり、 $\mathbf{n}^{\mathrm{P}}$ は特解、 $\mathbf{n}^{\mathrm{c}}$ は余解である。 $\mathrm{n}^{\mathrm{P}}$ と $\mathrm{n}^{\mathrm{c}}$ は独立な解であ るから、式(A.6)を式(A.3)に代入しても成立しなければならないの で次式が得られる。

$$
\mathbf{S}\left[\mathrm{Im}-\mathbf{B}^{+} \mathbf{B}\right] \boldsymbol{\beta}=\mathbf{0}
$$

また、式(A.4),(A.5),(A.6)より、

$$
\mathbf{n}=\mathbf{B}^{+} \mathbf{f}+\left[\mathbf{I m}-\mathbf{B}^{+} \mathbf{B}\right] \boldsymbol{\beta}
$$

である。上式は本文式(4.1)と同じである。次に、本文式(4.8) (4.9) より、式(A.7)の左辺を $\Delta l^{\mathrm{c}}$ とおくと、

$$
\Delta l^{\mathrm{c}}=\mathbf{0}
$$

すなわち、式(A.7)は適合条件であることが分かる。

$\Delta \boldsymbol{l}^{\mathrm{c}}$ と $\mathrm{n}$ に対して仮想仕事の原理を使って、 $\mathrm{n}$ と $\mathbf{u}$ を求める方 法は本文式(4.13) (4.17) に示した通りであり、古来、仮想仕事法 として親しまれて来た方法で、何等の新味もない。それに対し文献 3）に示してある方法は、Bot t- Duff in 䖢行列を用いて応力解を求 める方法で、新しく優れた方法であるが難解である。

\section{参考文献}

1）J.ロビンソン著、川井忠彦、他 5 名共訳 : 技術者のためのマトリックス構 造解析法、培風館，pp.169-226,1979.11

2）柳井晴夫、竹内 啓: 射影行列 - 一般逆行列 - 特異值分解, 東京大学出版 会, 1983.7

3) M.Domaszewski and A.Borkowski ; Generalized Inverses in ElasticPlastic Analysis of Structures, Journal of Structural Mechanics, Vol. 12,No.2,pp.219-244,1984

4）田中尚、半谷裕彦: 不安定トラスの粑体变位と安定化条件, 日本建筑学 会構造系論文集, NO.356, pp.35-43，1985.10

5）半谷裕彦、川口健一：形態解析一般逆行列とその忘用, 培風館, 1991.4

6) 和田 章、久保田英之: 不安定構造物の解析法に関する研究、日本建築学 会構造系論文集, NO.387, pp.35-44, 1988.5

7）西村 督、森迫清貫 : 固有值問題の振動展開による钓合释路上の䠛界点予 測手法、日本建築学会構造系論文集, NO.522, pp.45-50, 1999.8 